AJIT-e: Online Academic Journal of Information Technology

2019 Bahar/Spring - Cilt/Vol: 10 - Sayı/Num: 37

DOI: 10.5824/1309-1581.2019.2.006.x

http://www.ajit-e.org/?menu=pages\&p=details_of_article\&id=402

Received: 25.12 .2018

Editorial Process Begin: 20.02.2019

Published: 15.06.2019

\title{
Yeni Medya ve İnternet Haberciliğinde Etik Sorunlar
}

Emre ÖZCAN, Marmara Üniversitesi Sosyal Bilimler Enstitüsü ozcannemre@gmail.com

Öz Etik; genel olarak, geçmiş, günümüz ve gelecekte insanların davranışlarının iyi ya da kötü, doğru veya yanlış yönden değerlendirilmesini içeren ve dünyanın her yerinde geçerli olması beklenen ilke ve kuralların bütünü olarak tanmmlanabilir. Bu çalısmada, internet haberciliği ve Türkiye'de yayın yapan internet haber sitelerinin habercilik etiğine bakışıla ilgili örnekler eşliğinde değerlendirmeler yapıldı. Çalışmada etik, ahlak, meslek etiğ i, medya etiği, internet haberciliğinin etik sorunları gibi konularda site incelemesi yapıldı. Incelenen haberlerin kamuoyunu bilgilendirme amacından çok tık haberciliğine hizmet ettiğgi ve eğlendirme amacına hizmet ettiğgi görüldü. Ayrıca bu makalede internet haberciliğinin olumlu ve olumsuz yönlerini tartışarak haberleri medya etiği açısından tartışı k. Internet haber siteleri medya etiğ i değerlerine riayet ediyor mu? gibi sorulara cevap aradiğımız çalışmada birçok örnekle bu değerlerin nasıl çiğnendiğgi bir kez daha ortaya çıktı.

Anahtar kelimeler: Etik, Gazetecilik Etiği, Medya Etiği, İnternet Haberciliği, İnternet Etĭği

Abstract Ethic; In general, past, present and future people's behavior can be defined as the whole of the principles and rules that are expected to be valid in all parts of the world, including good or bad, right or wrong evaluation. In this study, Internet journalism and broadcasting in Turkey evaluations, accompanied by examples of internet news sites was done with a view to journalistic ethics. In the study, the subject of ethics, ethics, professional ethics, media ethics, ethics issues of internet journalism were examined. It has been seen that the news reports serve the press service rather than informing the public and serve the purpose of entertaining. In this article, we discussed the news in terms of media ethics by discussing the positive and negative aspects of internet journalism. Do Internet news sites respect media ethics? In the study we are looking for answers to questions such as how many times these values have been broken.

Keywords: Ethics, Journalism Ethics, Media Ethics, Internet News, Internet Ethics

\section{GíRiş}

Yeni Medya; gelişen bilgisayar, internet ve mobil teknolojisi ile ortaya çıan, kullanıcıların zamandan ve mekandan bağımsız bir şekilde interaktif olarak etkileşimde bulundukları sanal medya ortamidir.

Geleneksel medya dediğimiz, yazılı ve görsel basında yani gazete, televizyon ve diğer araçlarda, iletim tek yönlüdür. Ancak, yeni medya araçlarında hedef kitle ile karşılıklı etkileşim mevcuttur.

"Yeni" olarak belirttiğimiz kavram aslında mesaj değil, ortamdır. Tarih boyunca insanlar ve toplumlararası bir mesajlaşma olmuştur. En ilkel mağara duvarları yazılarından tutalımda günümüz son sürat teknoloji iletilen bilgiye kadar, temel amaç hep mesajın taşınması olmuştur. işte bu bağlamda bilginin taşınması "günümüz" itibarı ile "yeni" ortamlar ve mecralar ile taşındığından dolayı "yeni medya" kavramı ortaya çıkmıştır. (YÜKSEL, 2012) 
Medyanın tek görevi gazeteciliğin temeli olan 5N 1K'nın "ne" sorusuna cevap bulmak değildir. Yeni medya büyük ölçüde "şuan ne oluyor" sorusuna hızlıca cevap vermeyi temel işlevi olarak algılamaktadır. Ancak gazetecilikte daha önemli olan sorular "neden" ve "nasıl" sorularıdır.

Haber toplama, işleme,sunum ve dağıtım faaliyetleri de bir değişim sürecine girdi. Haberciler değil onların haber kaynakları da gelişen ve çeşitlenen bu teknolojilerden, yararlaniyor. Gazeteciliğin özü olan "muhabirlik" sisteminden, daha ziyade bir denetim ve düzenleme sistemi olan "editörlük" sistemine geçiş yaşanmıştır.

Haber çok farklı formlarda düzenlenebilir, tasarlanabilir,sunulabilir. Okura yeni perspektifler sunarak

katilım

sağlanabilir. Metnin yanı sıra, görüntü, ses, grafik ve diğer multimedia

araçlarından yararlanılabilir. (Karaduman)

Çünkü gazeteciliğin özü olan "muhabirlik" sisteminden, daha ziyade bir denetim ve düzenleme sistemi olan "editörlük" sistemine geçiş yaşanmıştır. Oysaki editoryal sistem için öncelikle haber gereklidir. Haber ise yalnızca internetten, ajanslardan, oradan buradan toplanıp makyajlanan bir şey değildir. Haber, araştırmadır, haber özgünlüktür, haber röportajdır, haber emektir. Özellikle Türkiye'de internet gazetelerini incelediğimizde haberciliğin özünden gitgide uzaklaşan, internet ve ajanslardan gelen haberlere sadece "çarpıcı" başlık bulma üzerine kurulmuş bir anlayışın egemenliğinden söz etmek yanlış olmayacaktır. Elbette alternatif haber kaynakları ve internet siteleri yok değildir. Ancak bu alternatif haber kaynakları çok azınlıktadır.

Dolayısıyla haberciliğin kolaycılı̆̆a endekslendiği bir bakış Türkiye'de yeni medyada hakim olan anlayıştır. Bunun nedeni ise kolayca anlaşılabilir. İnternet gazeteleri en temel işlevleri olan "haber verme", "toplumdaki farklı fikirler için forum oluşturma", "yönetenleri kamuoyu adına denetleme" yerine iki işleve yönelmişlerdir: Eğlendirme ve En fazla tık alma.

Geleneksel yayıncılıkta ne sunulursa onu alan izleyici, dijital yayıncılıkta yayın kaynağını ve bu kaynaktan ne alacağını kendi seçerek tek yönlü iletişim halkasını kırmaktadır. Zira dijital yayıncılık sadece platform olarak kullanıcısına sunduğu teknik olanaklar ile değil, yayın dinamikleri arasında yer alan etkileşimli hizmetleri ile de kullanıcısını aktif kılmaktadır. Bankacılık faaliyetleri, alışveriş, oyunlar ve sosyal medya bağlantılı uygulamalar bu hizmetlere örnek teşkil etmektedir. 196 Bilgi işlem ve iletişim teknolojilerini bir arada barındıran yapısıyla yeni medya, kitlesel izleyicilere sürekli program akışı sunan geleneksel radyo TV yayıncılığının biçimsel kalıplarını böylece kırmıştır. Geniş kitlelere yönelik yayıncılığın yerine daha dar ölçekte tanımlanmış, görece türdeş gruplara yönelik yayıncılık güçlenmiştir. Sunulan paket içeriğinin bu programlara göre (paket programlar olarak) ayarlanabilmesi, alıcının istediği anda istediği bilgiyi seçip kullanabilmesi, yeni medyanın kitle iletişim araçlarının program akışı ile arasındaki farkı ortaya koymaktadır. Radyo/TV içeriği genel olarak aynı kitle izleyicisine iletirken, yeni medya (dijital yayıncılık, yüksek çözünürlüklü televizyon-HDTV, teletext, videotext, videokonferans vb) önceden hazırlanmış 
içerikleri farklı kişi ya da gruplara, farklı zamanlarda ve mekanlarda, değişebilen program akışları ile iletilebilmektedir.

\section{Yeni Medya ve Etik}

Yeni medya ve beraberinde getirdiği çok seslilik, son y1llarda medyada meydana gelen ekonomik dönüşüm ve beraberinde getirdiği işadamı-gazeteci kimliğine bir tepki ve aynı zamanda çözüm niteliği taşımaktadır. Görece küçük ölçekli yeni medya kurumları ana akım medya ile iktidar arasındaki ekonomik ilişkilerden bağımsız faaliyet gösterdiği, her düşünceye yer verdiği ve tüm kullanıcılara demokratik bir biçimde düşüncelerini paylaşma imkânı verdiği için yeni ve korunması gerekli bir özgürlük alanı yaratmaktadır.

\section{Görsel 1 Etik Sorunlar - Yanıltma ve Manipülasyon}

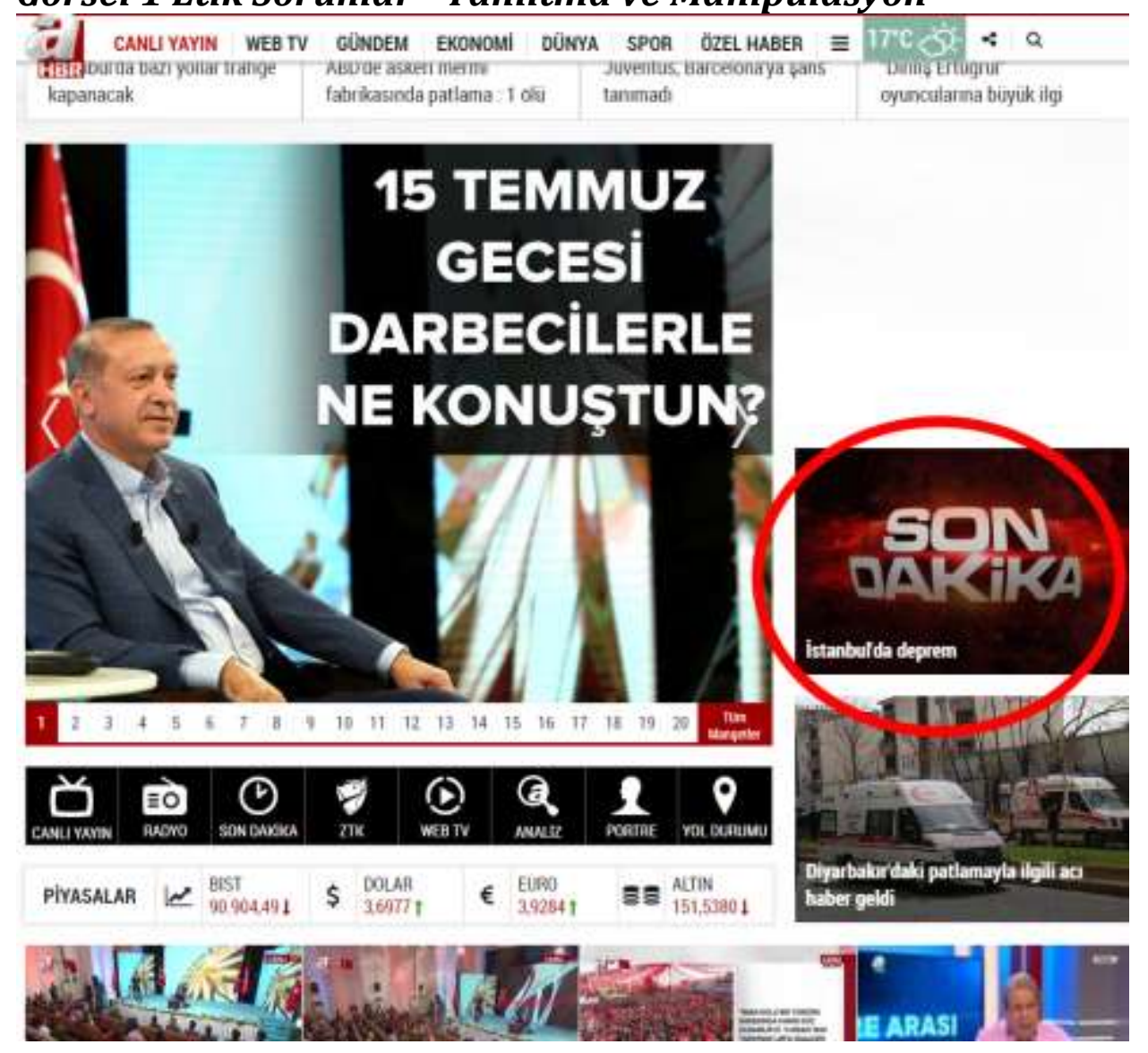

$\mathrm{Bu}$ alanın verimli ve demokrasiyi geliştirici bir nitelik taşıması ise yoğun denetim mekanizmaları ve hukuki yaptırımlar çerçevesinde değil kullanıcıların önemli bir toplumsal kurum haline gelen medya konusunda bilinçlendirilmesi ve medyanın doğru analizi ile mümkün olacaktır.

Yukarıda saydığımız olanaklar yeni medyada haberciliğe yeni bir boyut getirmekle beraber teknolojinin yoğun biçimde kullanımıyla birlikte bazı etik ihlallerini de beraberinde 
getirmiştir. Alternatif Bilişim Derneği Yeni Medya Çalışma Grubu'nun 04.06.2011'de gerçekleştirilen Çalıştay'da bu husus üzerinde durmuş ve yeni medya üzerinden etik ihlallerini araştırmıştır. Tespit edilen sorunlar şöyle sıralanmıştır; Özel yaşamın gizliliği, telif / patent haklarının ihlali, içeriğin asıl kaynağının gösterilmemesi, üretilen içeriklerin olgunlaşmadan ve doğruluğunun teyit edilmeden yayılması, kişisel verilerin güvenliği, haber ve ticari enformasyonun sınırlarının belirsizleşmesi, yeni medya özellikleriyle kullanıcının yoğun reklama maruz bırakılması, toplumsal cinsiyet eşitsizliğinin yeniden üretilmesi, içeriklerin yanıltıcı bir biçimde etiketlenmesi ve başlıklandırılması, nefret söylemi, söylemsel pratiklerdeki sorun, dilin özensiz kullanımı, bireyin yeni medya ortaminda tüketici olarak konumlandirılması. (https://www.alternatifbilisim.org/wiki/Yeni Medyada Etik Sorunlar, 06.12.2014)

\section{Görsel 2 Etik Sorunlar - Manşette Reklam Aldatmacası}

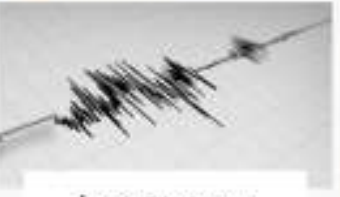

Istanbui da deprem

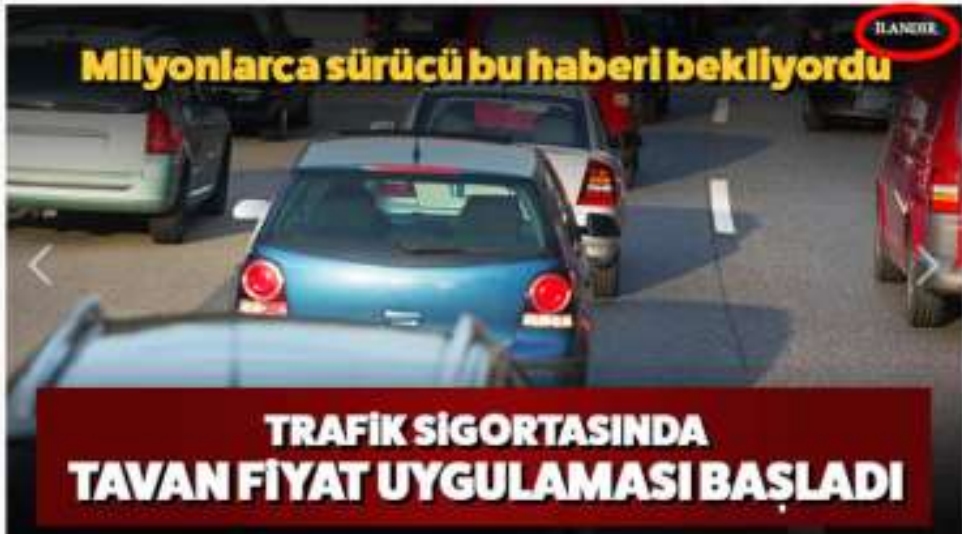

\begin{tabular}{llllll|l|l|llllllllllllllllll}
\hline 1 & 2 & 3 & 4 & 5 & 6 & 7 & 3 & 9 & 10 & 11 & 12 & 13 & 44 & 15 & 16 & 17 & 18 & 19 & 20 & 21 & 22 & 25 & 24 & 25 & $T$
\end{tabular}

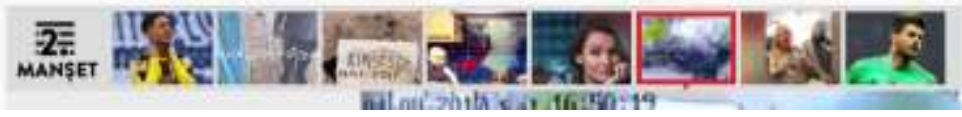

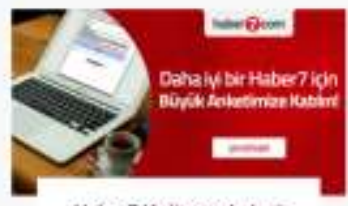

Haber7 Kullanıci Anket

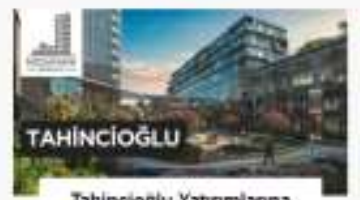

Thinoiogiu Yatunmlonn Devam Ediyor

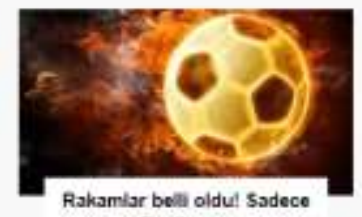

Beşiktas...

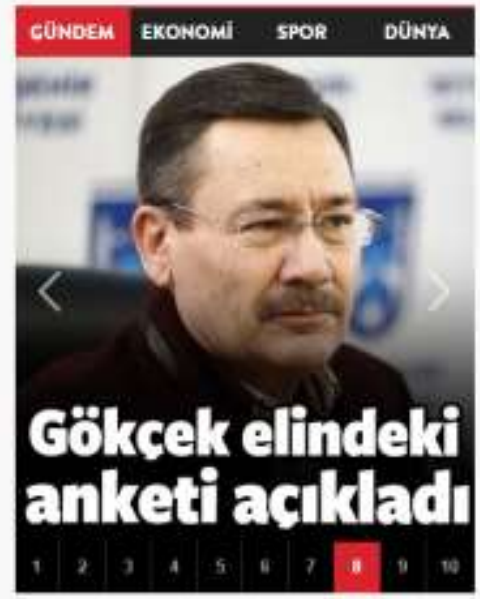

Birbirleriyle oldukça bağlantılı gördüğümüz söz konusu ihlaller, genel anlamda sahte içerik üretimi, özel hayatın ihlali, haber ve ticari enformasyonun sınırlarının belirsizleşmesi ve yeni medyanın cinsiyet ayrımcılığı ve nefret söyleminin yaygınlaşması için sağladığı geniş ortam olarak sinurlanabilir. (Vardal, 2015) 
Haber siteleri reyting ölçümlemede Mozilla Firefox tarayıcısına eklenen 'Heat Map' uzantısı sayesinde okurların elektronik izlerini takip ederek reklam stratejilerini belirliyorlar. Ayrıca haber siteleri kullandıkları editör panelinde anlık olarak hangi haberin ne kadar tıklandığını takip ederek hangi haberin manşetten indirileceğine karar veriyorlar. Okurların en çok tıklama eğilimi gösterdikleri yerlere reklam haberleri yerleştiren siteler gelişen teknoloilerin getirdiği bu teknik imkanlar sayesinde okuyucusunun nereye tıklayacağını adeta önceden bilme şansına sahip oluyor.

\section{Yeni Medyada Nefret Söylemi}

Yeni medya ortamında homofobik, transfobik, heteroseksist cinsiyetçi, yabancı düşmanı, ırkçı, etnik milliyetçi ve politik-ayrımcı nefret söylemi ortamın özelliklerinden dolayı çok daha kolay bir şekilde yaygınlaşarak, sıradanlaşarak dolaşıma giriyor.

İnternet ve sosyal paylaşım ortamlarında kullanıcıya sunulan özgürlük ortamı, ortamdaki birey ve toplulukların başka kişilere ve gruplara karşı, ırkçı düşüncelerini, öfkelerini, nefretlerini denetimsiz bir biçimde ifade ettikleri bir alana dönüşmektedir

Nefret söylemi geleneksel medyada genellikle abartma, çarpıtma, ima veya kinaye yeni medya ortamlarında ise küfür, hakaret, aşağılama olarak ortaya çıkar. (ÖZTEKİN, 2015)

\section{Görsel 3 Nefret Söylemi- Barbaros Şansal Haberi}

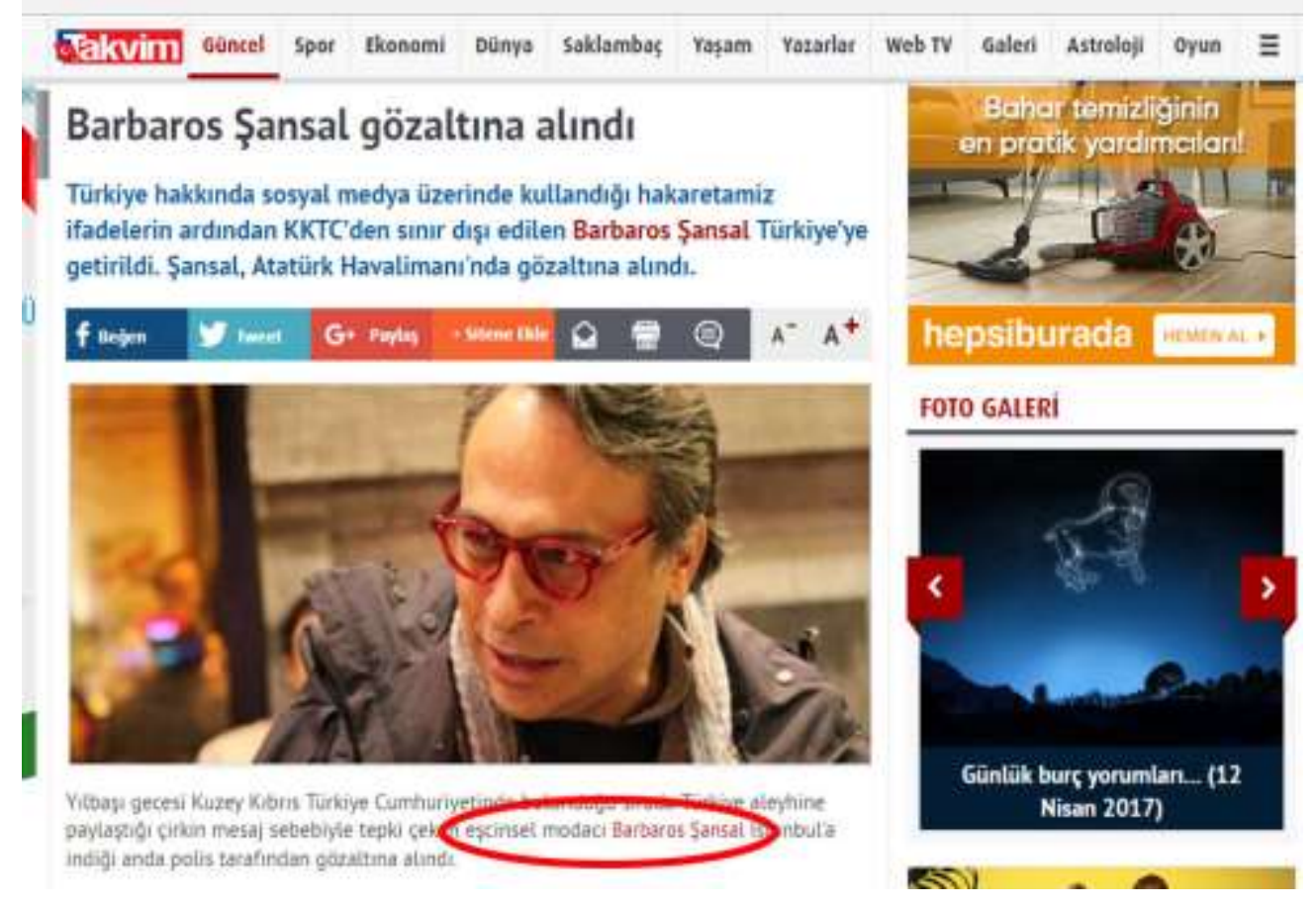

Nefret Söylemi ile Mücadelede Yeni Medya Her geçen gün ilerleyen iletişim teknolojileriyle beslenen ve güçlenen yeni medya, günümüzde bir yandan kullanıcı içerikli ve kullanıcı yorumlarıyla desteklenen yapısıyla demokratik bir görünüm sergilemekte, diğer yandan ana akım medyanın internet üzerinden de yayın yapmasıyla geleneksel medyayla paralelleşen 
bir yapıya bürünmektedir. Ancak yeni medyayı geleneksel medyadan farklı ve özgün kılan teknolojik altyapısından ziyade kullanıcı kaynaklı içerikleri ve etkileşime izin veren yapısıdır. Nefret söylemi ile mücadelede kullanılması gereken asıl özellik de kanımızca bu noktada karşımıza çıkmaktadır. Geleneksel medya açısından baktığımızda sadece eleştirel bir okuma sağlayabilecek medya okuryazarlığı, yeni medya söz konusu olduğunda farklı bir anlama bürünmekte; bu alanda yetkin kullanıcılar, haber içeriklerine ve Zeynep Burcu Vardal - Nefret Söylemi ve Yeni Medya 152 başlıklarına eleştiriler yönelterek müdahale edebilmekte ya da diğer kullanıcılara farklı bir bakış açısı sunabilmektedir. Ancak yeni medyanın nefret söylemiyle mücadelede sadece etkin bir araç olarak kullanılabileceğini vurgulamakta fayda görülmektedir. Öncelikle yapılması gereken toplumun nefret söylemine karşı eğitilmesi ve bilinçlendirilmesidir. $\mathrm{Bu}$ da ilköğretimden itibaren verilecek medya okuryazarlığı dersinin yanında aile, eğitim, din gibi farklı toplumsal kurumların toplumu nefret söylemi ve nefret suçları üzerine bilinçlendirmesi ile mümkün olacaktır. Ancak bu, sonuçları ilk anda görülemeyecek uzun soluklu bir çözüm yöntemi olarak karşımıza çıkmaktadır. İnternet her ne kadar denetimi güç bir alan olsa da ihbar hatlarıyla desteklenen yasal düzenlemeler de caydırıcı özelliği ve korunması gereken hak ve özgürlüklerin niteliği nedeniyle üzerinde durulması gereken bir husustur. Türkiye' de internet kullanımına ilişkin yasal düzenlemeler 5651 Sayılı “İnternet Ortamında Yapılan Yayınların Düzenlenmesi ve Bu Yayınlar Yoluyla İşlenen Suçlarla Mücadele Edilmesi Hakkında Kanun”da yer almaktadır. Söz konusu kanun, 8. maddesiyle "Erişimin Engellenmesi Kararı ve Yerine Getirilmesi"ni düzenlerken; 9. maddesiyle ise "İçeriğin Yayından Kaldırılması ve Cevap Hakkı"nı düzenlemektedir.

\section{Görsel 4 Nefret Söylemi - Gani Müjde Haberi}

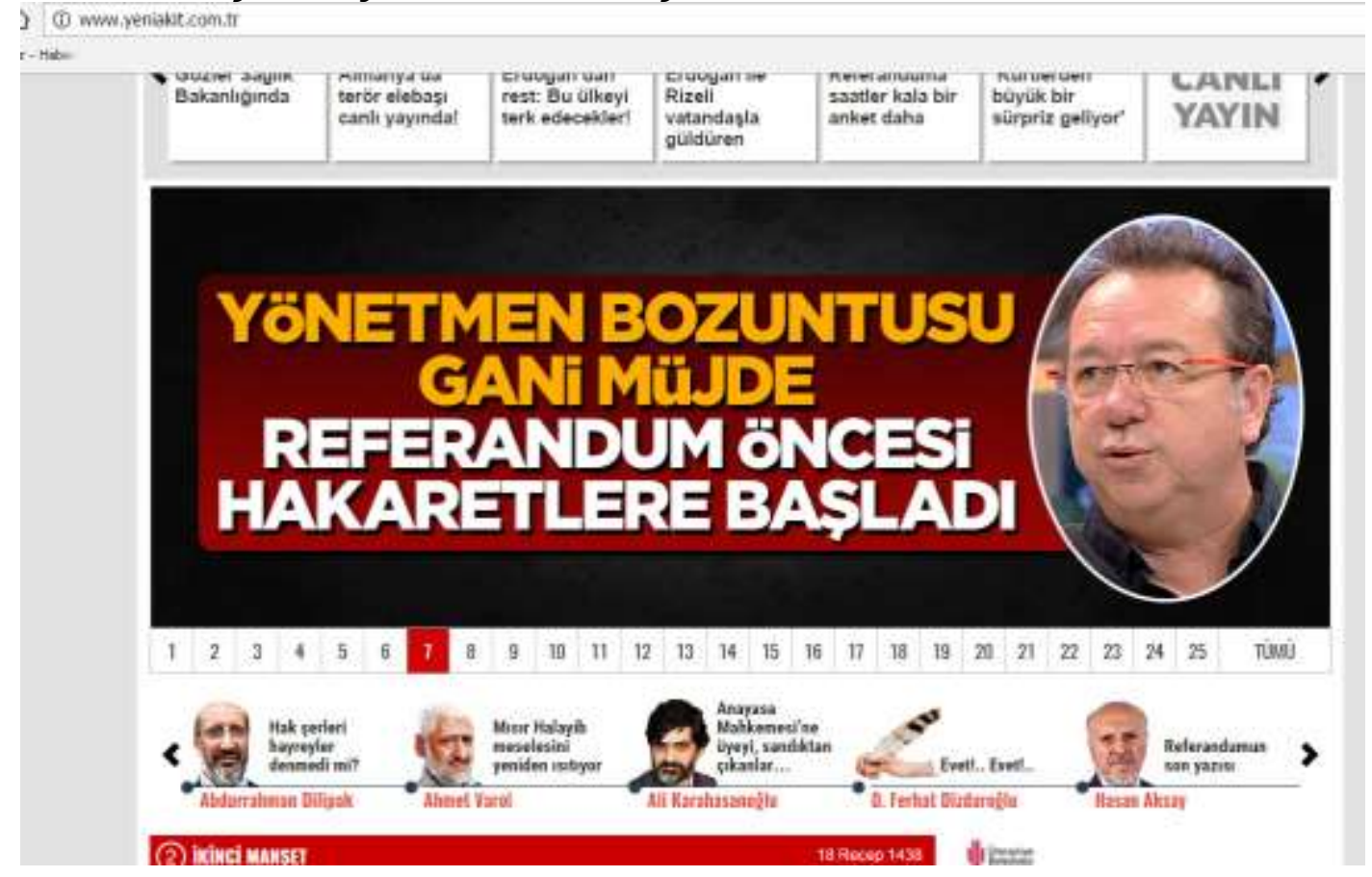


Nefret söyleminin bu kapsamda değerlendirilmemiş olması önemli bir sorun olarak karşımıza çıkmaktadır. Nitekim bu alanda yasal yaptırımların yetersizliği yeni medyanın, kullanıcıların etik anlayışına terk edilmiş denetimsiz bir mecra oluşturduğu yönündeki görüşümüzü desteklemektedir. 5651 Sayılı Kanunun ilgili maddelerinin ve bu doğrultuda, Telekomünikasyon İletişim Başkanlığı tarafından kendi internet sitelerinde aktif hale getirilen ihbar mekanizmasının, nefret söylemi içeren paylaşımları da dâhil edecek şekilde geliştirilmesi gerekmektedir. (Vardal, 2015)

Avrupa Konseyi'nin Bakanlar Komitesi tarafından yayınlanan "nefret söylemi" konulu 97(20) sayılı Tavsiye Kararı'nda söz konusu kavram şu şekilde tanımlanmıştır:

“'Nefret söylemi' kavramı, ırkçı nefreti, yabancı düşmanlığını, Yahudi düşmanlığını veya azınlıklara, göçmenlere ve göçmen kökenli insanlara yönelik saldırgan ulusalcılık ve etnik merkezcilik, ayrımcılık ve düşmanlık şeklinde ifadesini bulan, dinsel hoşgörüsüzlük dâhil olmak üzere hoşgörüsüzlüğe dayalı başka nefret biçimlerini yayan, kışkırtan, teşvik eden veya meşrulaştıran her türlü ifade biçimini kapsayacak şekilde anlaşılacaktır. Bu anlamda "nefret söylemi" muhakkak belirli bir kişiye veya gruba yönlendirilmiş yorumları kapsamaktadır." (http://www.ihop.org.tr/dosya/coe/nefret soylemi.pdf 11.12.2014.)

Yeni medyada cinsiyet ayrımcllı̆̆ ve nefret söylemi daha çok sosyal paylaşım sitelerinde karşımıza çıkmakta; suç unsuru oluşturan içerik ve yorumlar internette rahatlıkla dolaşıma girebilmektedir. Gazetecilik mesleği çerçevesinde değerlendiremeyeceğimiz bu durumun en azından kurumsallaşmış haber sitelerinde denetlenmesi öncelikli önem taşımaktadır.

\section{Görsel 5 Nefret Söylemi- Gani Müjde Haberi Yorum Sayfası}

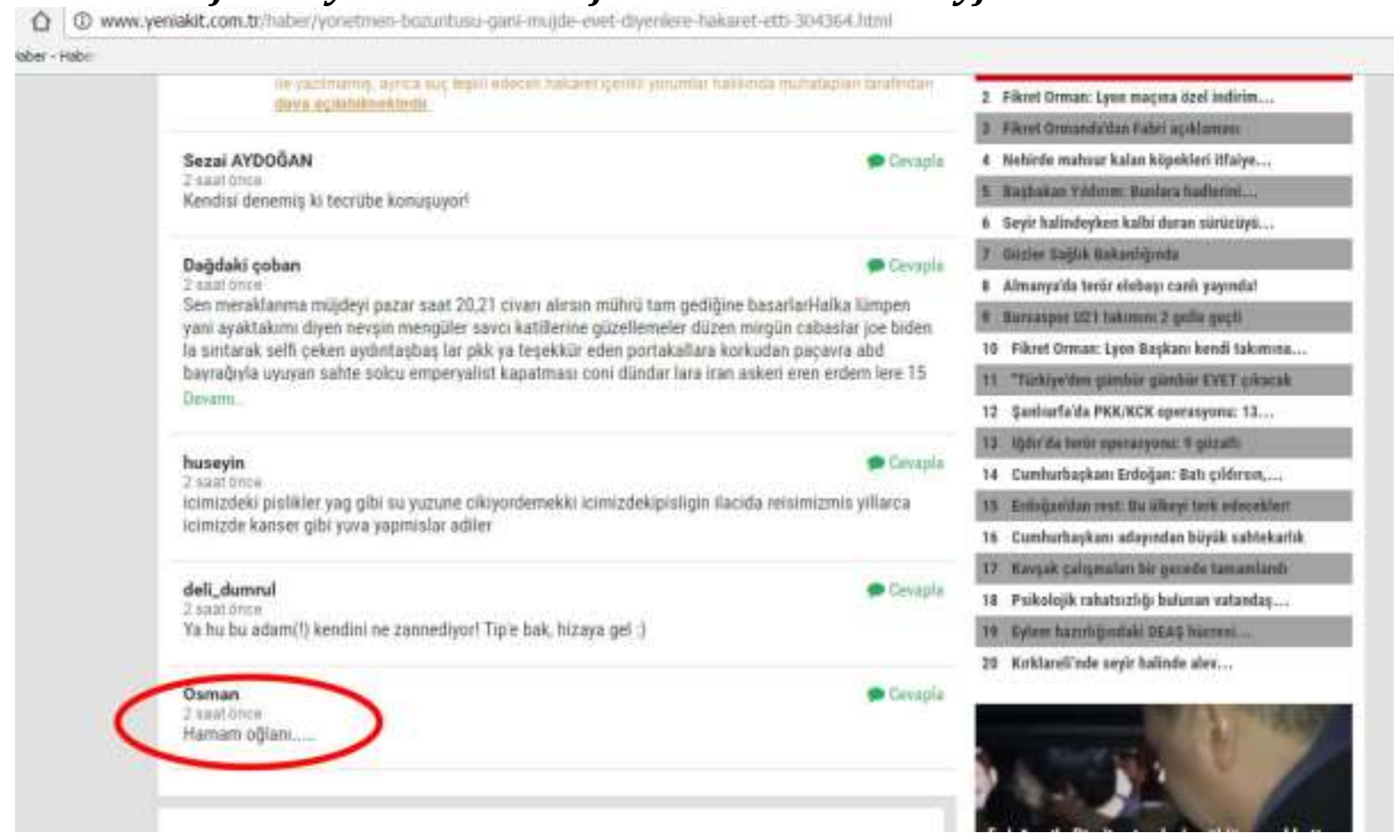

Nefret söylemi sosyal medya ile başlamamış ancak sosyal medya aracılığıyla kendine yeni ve güçlü bir mecra bulmuş ve toplumun genelini etkileyecek şekilde yaygınlaşmıştır. 
Bununla birlikte son yıllarda artan nefret söylemlerine ilişkin olumlu bir gelişme olarak Tİ'in özel bir şikâyet mekanizması oluşturduğu görülmektedir. Benzer biçimde Hrant Dink Vakfı da 2009 yılından beri yürüttüğü Medyada Nefret Söylemi'nin İzlenmesi Projesi'yle bu alanda önemli çalışmalar yapmaktadır.

\section{Görsel 6 Nefret Söylemi- Hüsnü Bozkurt haberi yorum sayfası}

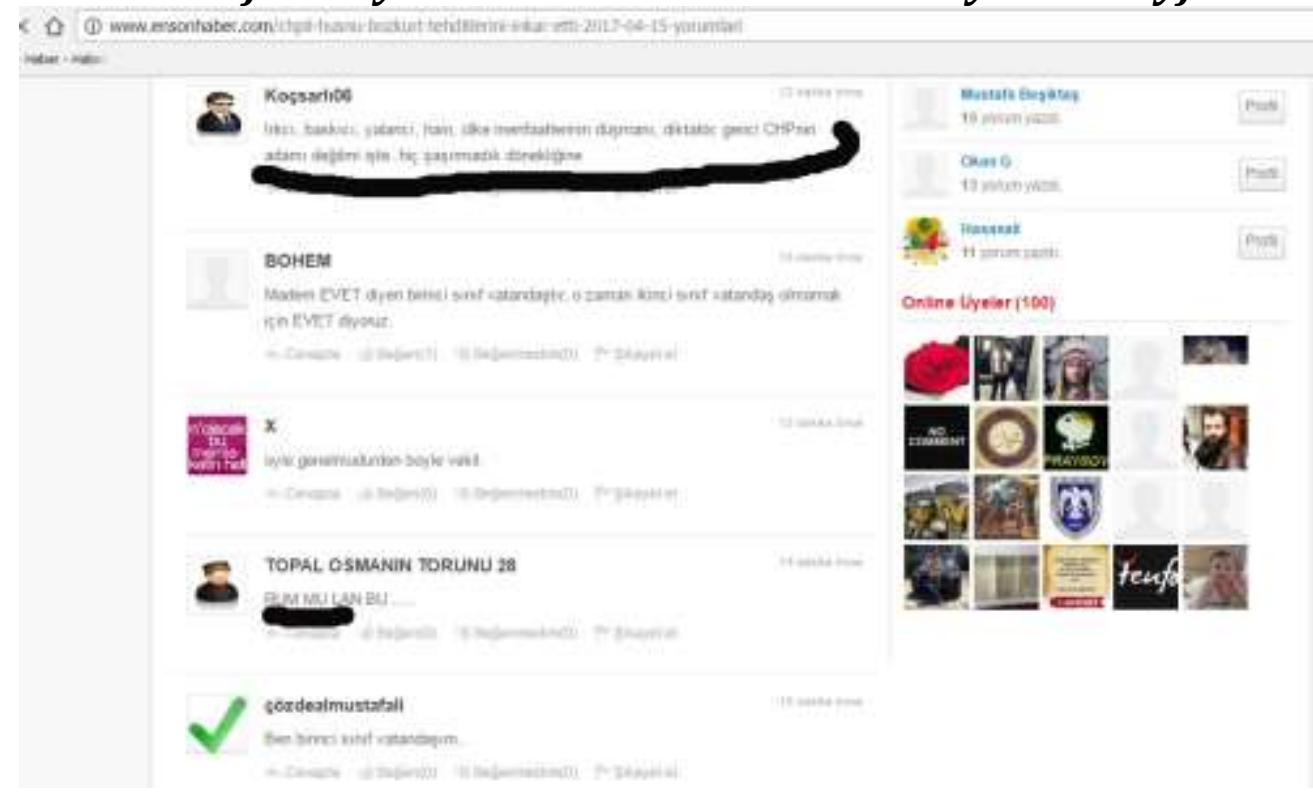

Hrant Dink Vakfı, İnternet sitesinde kurumun çalışmaları şöyle özetlenmektedir; "Çalışma kapsamında, ulusal ve yerel yazılı basın taranarak ayrımcı, ötekileştiren ve hedef gösteren bir söylemle kaleme alınmış haber ve köşe yazıları tespit ediliyor. Esas olarak ulusal, etnik ve dini kimlik temelli nefret söylemine odaklanılırken, homofobik ve cinsiyetçi söylemler de tarama kapsamına alınıyor. $\mathrm{Bu}$ içerikler, $\mathrm{k}$ ssa analizleriyle günlük olarak www.nefretsoylemi.org sitesine yükleniyor ve Facebook ve Twitter gibi çeşitli www.aasrc.org/imaj International Multilingual Academic Journal Vol. sosyal medya ağları aracılığıyla teşhir ediliyor."

Söz konusu kurumun çalışmaları, sosyal paylaşım siteleri aracılığıyla yeni bir yayılım olanağı bulan nefret söyleminin aynı araçla teşhirini amaçlamaktadır. Kanımızca nefret söylemi sadece yeni medyanın desteklediği boyutuyla değil toplumsal bir sorun olarak incelenmelidir. Nitekim toplumların farklı etnik, dini ya da ulusal kimliklere olan yaklaşımı ya da homofobi ve cinsiyet ayrımcılığına olan genel bakışı gelişmişlik düzeyini gösteren önemli bir etkendir. Bununla birlikte eğitim seviyesi de nefret söylemine çözüm üretmekte yetersiz kalabilmekte toplumda yerleşmiş tutucu olarak değerlendirilebilecek kanıların değişmesi zaman alabilmektedir.

Özellikle internet haber sitelerinin yorum kısımlarında ağırlıklı olarak etnisiteye dayalı nefret söylemi içeriğine rastlanır. Ermeni, Yahudi, Rum, Yunan dölü gibi kavramlar 
kullanılan hakaretler arasında en belirgin olanlarıdır. Bunların yanı sıra cinsel kimliğe dayalı, "ibne", "karı", "dönme" gibi hakaretler de sıklıkla karşımıza çıkmaktadır. En genel haliyle "biz", “Türk", “Beyaz", "Sünni Müslüman", “Heteroseksüel” ve "Erkek" olarak tanımlanabilecek unsurlardan oluşmakta ve bu unsurların dışında kalan herkes nefret söyleminin hedefi olmaktadır."

Dirini'nin dört internet portalı üzerinde katılımsız gözlem yöntemiyle yaptı̆̆ı bir araştırmaya göre; "Yorumlar habere/yazıya konu olan olaya ilişkin fikir beyanlarından ziyade fanatik/taraf bildiren/hakaret içeren tarzda yazılmaktadır. İncelenen dönemde yorumların en çok etnik temelli haberlere yapıldığı görülmüştür. Buralarda nefret söylemi yaygın olarak kullanılmaktadır. (Ortalama olarak \%80). Haberin içeriğinden alabildiğince uzaklaşan yorumlarda yorumcular birbiriyle de kavgaya tutuşabilmekte, yorumcular arasında bile bir kutuplaşma yaşanabilmektedir."

\section{Yeni Medyada Kişisel Verilerin Kullanımı}

İnternet ortamı, özellikle de sosyal medya normal şartlar altında tanımadığımız kimselerle paylaşmayacağımız kişisel bilgilerimizi hatta bankacılık bilgilerimizi rahatlıkla paylaştığımız bir alan haline geldi. Çoğumuzun özgürlük olarak nitelendirebileceği bu durum diğer yandan denetlenmesi imkânsız gibi görülen internet aracının çok güçlü bir denetim aracı haline geldiğine de işaret etmektedir. Bu bağlamda kişisel verilerin güvenliği internet ortamında kullanıcıların şimdilik görmezden geldiği en ciddi sorun olarak karşımıza çıkmaktadır.

"Kişisel veri, genel hatlarıyla bir bireyin şahsen tespit edilmesine veya bir kişinin bir birey olarak diğerlerinden ayırt edilmesini sağlayan her türlü bilgi demektir." (Binark, Bayraktutan, 2013:73) İnternet kullanıcılarının çoğunlukla dikkat etmediği husus herhangi bir sitede bir kez paylaştıkları bilginin daha sonra karşısında çıkmasıdır. Bununla birlikte reklamcılar açısından kesin bir ekonomik değeri olan kişisel bilgileriniz ve iletişim bilgilerinizin herhangi bir alışverişe konu olup olmadığını da bilemezsiniz. Bu konuda Birsen'in yaptığı bir araştırma, “Türkiye' de internet yayıncılığı yapanların okur bilgilerinin özel hayat sınırları içine girdiğinin, kendileri ve siteleri için yararlı olduğunun, bu bilgilerin toplanma gerekçesi ve kullanma amacı konusunda izlerkitlenin bilgilendirilmesi gerektiğinin farklı olduğunu göstermektedir." (Birsen, 2005:77) Ancak bu bilgilerin nasıl kullanıldı̆̆ına ilişkin somut verilerin olmadığı unutulmamalıdır.

Diğer taraftan haber siteleri kişisel bilgilerinizle birlikte ilgi alanlarınızı da depolamaktadır. Örnek olarak Hürriyet Sosyal uygulamasında herhangi bir köşe yazarını okumak için kişisel bilgilerinizle kayıt olmanız gerekmektedir. Ardından site sizden ilgi alanlarınızı belirlemenizi isteyecektir. Günümüz teknolojilerine uygun farklı bir gazetecilik olanağ sunan bu uygulama, yeni medyanın getirdiği olanaklardan sadece birisidir. Ancak bu durum bu bilgilerin haber sitesinin haberciliği kişiselleştirme ve farklı bir gazetecilik sunma anlayışı yanında gerek reklam verenlerin gerekse iktidar erklerinin ilgisini çekebilecek bilgilerinizi depoladığı gerçeğini de değiştirmez. Bir başka deyişle bu tarz uygulamaları kullandığınızda takip ettiğiniz köşe yazarlarından, ilginizi çeken haber konularına varana kadar her türlü ilgi alanınız depolanmaktadır. 


\section{Yurttaş Gazeteciliği}

Kavram olarak yurttaş gazeteciliği, ("halk gazeteciliği", "katılımcı gazetecilik", "demokratik gazetecilik", "gerilla gazeteciliği” ya da "sokak gazeteciliğì" olarak da bilinir) halkın "haber ve bilgiyi toplama, kaydetme, analiz etme ve yayma süreçlerinde aktif rol oynamasına dayanır. Yurttaş gazeteciliği, herhangi bir olay anında insanların cep telefonu, kamera vb. aygıtlar ile kaydettiği görüntüleri sosyal medyada paylaşması ile ortaya çıkmış gazetecilik örneğidir.

Yurttaş gazeteciliği, ikisi de profesyonel gazetecilerce uygulanan toplum gazeteciliği ya da şehir gazeteciliğiyle karıştırılmamalıdır. İşbirlikçi gazetecilik de aynı şekilde farklı bir kavramdır ve profesyonel ve amatör gazetecilerin birlikte çalışması şeklidir. Yurttaş Gazeteciliği ise yurttaş medya ve kullanıcı kaynaklı meydanın birlikte özel bir formudur. (Çakmak, 2012)

Yurttaş gazeteciliği olgusu, medyanın yaşadığı sorunları aşma çerçevesinde yeni bir alternatif gibi sunularak gündeme getirilmiş ve tartışılmıştır. 1990'larda ABD'de tartışılmaya başlanan yurttaş gazeteciliği pratiğinin ortaya çıkmasında etki eden faktörlere bakıldığında, ABD siyasetinin içinde bulunduğu durum, medya sektöründeki yoğunlaşmanın ortaya çıkardı ğ

Tarihte önemli yer kaplayan bazı olaylar olay yerindeki bireyler tarafından tesadüf eseri görüntülenmiştir. yurttaş foto-muhabirliği olarak isimlendirilen bu eylemlerin en önemli örneği “ABD başkanı John F. kennedy'nin dallas gezisi sırasında yaşamını yitirdiği suikastı görüntüleyen Abraham Zapruder'in bu görüntüleri o zaman 150 bin dolar karşılığında life dergisine satmıştır.

Günden güne artmakta olan cep telefonu egemenliğinin yanı sıra yeni medya teknolojisi, örnek olarak sosyal ağ ve medya paylaşım siteleri, yurttaş gazeteciliğini dünya çapında daha erişilebilir hale getirmiştir. Teknoloji kullanılabilirliliği sayesinde, yurttaşlar son dakika haberlerini geleneksel medya muhabirlerinden daha hizlı bir şekilde iletebilmektedir. Yurttaş gazeteciliğinin dünyanın başlıca olaylarını iletmekteki en dikkate değer örnekleri Arap Baharı ve Wall Street İsgali hareketidir.

Profesyonel gazetecilerin de aralarında yer aldığı muhalifler, yurttaş gazeteciliğinin belirli kurallardan yoksun, fazla subjektif, amatör ruhlu ve kalite ve kapsam bakımından gelişigüzel olduğunu iddia etmektedir.

Günümüz teknolojisiyle yurttaş gazetecilik hareketi, sıradan insanların haber yakalayıp, onu dünya çapında yayabilmesiyle yeni bir çehre kazanmaktadır.Yochai Bencler'in de belirttiği gibi, "Anlam kazandırabilme kapasitesi - insan için anlamlı ifadeleri kodlama ve çözme - ve bir şeyin anlamını dünya çapında bildirebilme kapasitesi küre üzerindeki en az birkaç yüz milyon kullanıcı tarafından desteklenmekte ya da kolayca ulaşılabilmektedir." Boston 
Üniversitesi anayasa hukuku profesörü, Profesör Mary-Rose Papandrea, Yurttaş Gazeteciliği ve Gazeteci İmtiyazı makalesinde şöyle belirmektedir:

"Gazetecilik"in tanımı, birçok yönden orjinal haline dönmüş durumda. "Basın özgürlüğü", ilk düzenlemenin yapıldığı yıl, basım işleriyle meşgul organize kuruluşların özgürlüğünü değil de bir matbaa makinesi kullanarak basım yapabilme özgürlüğünü kastediyordu hiç abartısız.

1775'in matbaacıları yalnızca gazete basmıordu; bunun yanı sıra emeklerinin çoğunu finansal açıdan hayatta kalabilmek için para ödeyen müşterilere materyal basmaya adamışlardı. Amerikan İhtilali devri gazete ve el broşürleri ağırlıklı olarak yanlıydı ve hatta bu, yüzyılın bitimine doğru daha da fazlalaştı. Haber toplama işiyle daha az meşgul oldular aksine genel olarak birer fikir taşıyıcıları haline geldiler.

"Gazetecilik" teriminin 1830 yılında yaygın kullanılır hale gelişi yüksek hızlı rotatif buharlı matbaa makineleri kullanan gazetelerin doğu Amerika boyunca yüksek tiraj elde edişiyle aynı zamana denk gelmektedir. Gazeteler matbaa makinesi kullanarak, birbirleriyle tamamen aynı kopyaları düşük ek maliyetle daha çok sayıda okuyucuya ulaştırabildiler. Dahası markalı ürünler için günden güne hızla artmakta olan reklam verme talebi, büyük çoğunluk reklamdan elde edilen karla finanse edilen ilanların oluşturulmasını ateşledi. "Basın" kavramının çoğunlukla rekabetçi, ticari bir medya teşebbüsüyle meşgul birey ve kurumlar tanımını edinmesi 19. Yüzyılın sonlarından önce olmamıştır.

\section{Arap Baharı}

Yurttaş Gazatecilik Arap Baharı'nın patlak vermesinde önemli bir rol oynadı.

\section{İşgal}

İşgal protestoları ayrıca Tim Pool ve Facebook üzerindeki Yurttaş Dergiler gibi yurttaş gazetecilerce yapılmış canlı interaktif medya yayınlarından da etkilendi.

\section{Yurttaş Gazeteciler}

Jay Rosen'a göre, yurttaş gazeteciler, tek bir yönde ilerleyen medya sisteminden olumsuz yönde etkilenenler kısmında, yayın kalıpları içinde, yüksek giriş bedelleri ve nüfusun kalanı birbirlerinden izole edilmiş bir şekilde dinlerken - ki bugün hiçbir şekilde bu durumda değiller ... yüksek sesle konuşmak için birbiriyle yarışan birkaç kuruluşun içinde kalmış “önceleri izleyici olarak tanınmış insanlar"dır. Önceleri izleyici olarak tanımış bu insanlar, daha fazla gerçek, yetkin, daha az imgesel, ön görülebilir hale dönüştürülen halkın ta kendisidir."

Başbakan John Fitzgerald Kennedy suikastını bir amatör film kamerasıyla kayıt altına almış Abraham Zapruder yurttaş gazeteciliğin bir atası olarak gösterilmektedir ara sıra. 
Halk Gazeciliği son günlerde, cep telefonları kullanımı gibi yeni medya üzerinden incelenmektedir. Cep telefonları haber iletme potansiyeline sahiptir ve bu gücü halkın ellerine yerleştirmektedir. Mobil telefonculuk insanlara haber operasyonu oluşturmaları konusunda düşük bütçeli seçenekler sağlamaktadır. Mobil haberler sağlayan ve halk gazateciliği üzerine çalışan küçük organizasyonların bir örneği Sri Lanka'daki Jasmine News'tir.

Mark Glaser ‘e göre, 2011 Eylül ayı boyunca süren Dünya Ticaret Merkezi üzerindeki terörist saldırılarına yönelik birçok görgü tanıklığı yurttaş gazatecilerden geldi. Merkezin yakınındaki yurttaş gazetecilerin anlattığı görüntü ve olaylar, hikayede önemli bir rol oynad1.

2004 yılında, 9.1 büyüklügündeki deniz altı depremi Endonezya'daki Banda Aceh bölgesinde devasa bir tsunami meydana getirdiği zaman, tsunamiye şahit olmuş birçok insandan gelen haberler büyük çoğunlukta yayınlandı.

Bir mikroblog olan Twitter, 2009 Iran Seçim Protestoları süresince, yabancı gazetecilerin etkin bir şekilde "haber yapmasının yasaklanması" sonrası önemli bir rol oynadı. Twitter, halkın iletişimdeki rolü nedeniyle İran'daki yayını durdurtacak protestolar boyunca önceden planlanan bakım çalışmalarını iptal etti.

Yurttaş Gazetecileri bazen aynı zamanda blog yazarları da olurlar ve bir süre sonra profesyonel gazetecilere dönüşürler, tıpkı Polonya'lı ödüllü blog yazarı vee gazeteci Pawel Rogalinski örneğinde olduğu gibi.

De, J.D.Lasica, yurttaş gazatecilik için medyayı aşağıdaki şekillerde tanımlar:

İzleyici Katılımı (örneğin haberlere, kişisel bloglara, kişisel cep telefonlarıyla çekilmiş fotoğraf ya da video metrajına ya da bir toplumun sakinlerince yazılmış lokal haberlere eklenen kullanıcı yorumları)

Bağımsız haberler ve bilgi siteleri (Consumer Reports, Drudge Report)

Tam Katılımcı haber siteleri (NowPublic, OhmyNews, DigitalJournal.com, GroundReport, fairobserver)

İşbirlikçi ve katkı sağlayıcı medya siteleri ( Slashdot, Kuro5hin, Newsvine)

"Hafif medyanın" diğer çeşitleri. (mail listeleri, email gazeteleri)

Kişisel yayın siteleri (KenRadio gibi video yayın siteleri)

Yeni medya teoristi Terry Flew "yurttaş gazeteciliği ve yurttaş medyanın yükselmesinde kritik" üç elementin olduğunu belirtir: Şeffaf yayıncılık, işbilirlikçi kurgu ve kapsamlı içerik. 


\section{Yeni Medyada Kişisel Yayıncılık}

Yurttaşlar varolan haberlere yorum, bloglama, fotoğraf ve video ekleyerek katkıda bulunabilir, bağımsız haber ve enformasyon siteleri açabilir, haberlerin kolektif olarak üretildiği siteler kurabilir, haber vermede eposta listeleri gibi araçları kullanabilir ya da kişisel yayın yaptıkları siteler kurabilirler. Bütün bunlar Terry Flew (2003)'ın yurttaş gazeteciliği için bahsettiği 3 önemli unsuru içerir: Açık yayın, kolektif, işbirliği içinde üretim ve içeriğin yaygınlaştırılması. Dün pasif bir şekilde okuyan ve izleyen bireylerin bugün aktif olarak dijital mecralarda içerik üretebildiği süreci tanımlıyor. (Saka, 2015)

Yurttaş gazetecilerce iletilen ve yayılan haberlerin hızıyla tehdit altındaki bazı başlıca haber yayınlama birimleri okuyucu ve finansal destek getirmesi açısından kampanyalar yapmaya başlamış durumda. Örnek olarak, birkaç Kuzey Kaliforniya gazetesi yayınlayan Embarcadero Medya müdürü Bill Johnson okuyuculardan finansal açıdan rahatlatmak üzere lokal gazetelere üye olmalarını isteyen online bir bildiri yayınladı. Johnson, ona göre "sakinler ve işyerlerinin değerini etkileyen, varsayımlarla savaşan ve eksikliklerimiz ve arzularımız üzerine ışık tutan" lokal gazetelerin kritik bir rol oynadığına dair özel bir vurgu yaptı.

Gazeteciliğin yeni medyada sosyal medya üzerinden büyük bir kısmının paylaşılması bu işi bilinçli veya bilinçsiz yapan kişileri çoğul becerilerini ortaya çıkardıkları düşünülmektedir. $\mathrm{Bu}$ çerçevede iletişim alanında çalışacak kişilerin "çoğul becerili" olmaları, temel gazetecilik becerilerine ek olarak yeni medyanın gerektirdiği mesleki becerilere de sahip olmaları istenmektedir. Bu becerilerin aynı anda sosyal medya üzerinde dönüşümü, geleneksel medyayı etkilemiş ve geleneksel medya çalışanlarını da bir nevi kurum çıkarlarına uygun hareket ettiren yurttaş gazetecilerine dönüştürmüştür. Sosyal medya üzerinde yeni medyanın bu kavram üzerinde şekillenmesi yeni bir haber anlayışı benimsetmiş, sıradan haber sayfalarını doldurmaya çalışan haberler yerine profesyonellerden internetin ve sosyal medyanın temel teknolojik özelliklerine ve sosyal bir platform olmasına uyum göstererek çoklu ortam niteliğinde, farklı mecralarda sunulabilecek üretim yapmaları beklenmektedir.

Herşeyin biraz daha kişiselleştiği günümüzde artık herkes kendi adına online gazete çıkarabilir konumda. Teknoloji konusunda en bilgisiz kişiler dahi tek tuşla, kolayca canlı yayın başlatabiliyor. Klasik medyanın bize dayattığı mizanpaj ve haberler yerine değer verilen haber kaynakları takip ediliyor. Ayrıca burada sayfa tasarımları reklam güdüsüyle tasarlanmiyor. (ÖZKAN, 2010)

\section{Yurttaş Gazetecilik Örnekleri}

San Jose Mercury News'in eski teknoloji köşe yazarı Dan Gillmor yurttaş gazeteciliğin önde gelen destekçilerinden biri ve gelişmesine yardım etmek üzere kar amacı gütmeyen Yurttaş Medya Merkezi'ni kurdu. Kanada Yayın Kurumu'nun Fransızca yayın yapan televizyon ağı da ayrıca haftada bir yayınlanmakta olan " 5 sur 5" adında bir halk meseleleri programı yayınlamakta ve 2001 'den bu yana yurttaş-temelli gazeteciliği tanıtmaktadır. Programda, 
izleyiciler çeşitli konularda sorular yöneltmekte ve halihazırda birer gazeteci olan kişilerin eşliğinde sorularına cevaplar alabilmek üzere uzmanlarla röportajlar yapabilmekteler.

New York Üniversitesi'nde gazetecilik profesörü Jay Rosen, halk gazeteciğinin en erken destekçilerinden biri oldu. 1993'den 1997 yılına kadar, Knight Foundation tarafından finanse edilen ve New York Üniversitesi'de bulunan Toplum Yaşamı ve Basın Projesi'ni yönetti. Rosen ayrıca son günlerde PressThink web bloğunun da başındadır.

\section{Görsel 7 Katılımcı Gazetecilik BBC Have Your Say Sayfası}

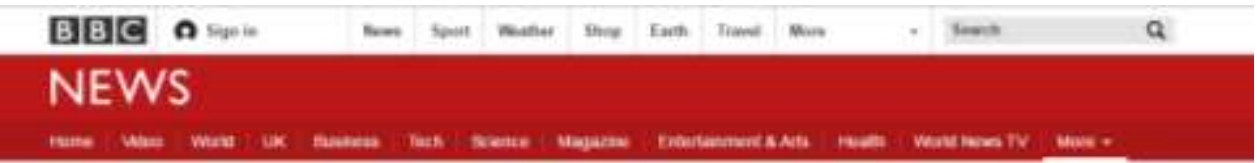

\section{Have Your Say}

\section{How to share with BBC News}
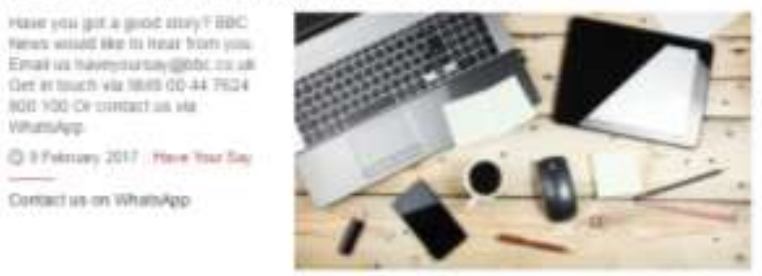

Share with BBC News?

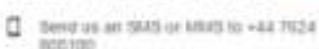

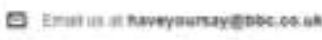

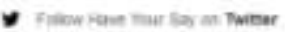

Cencer un on whanded
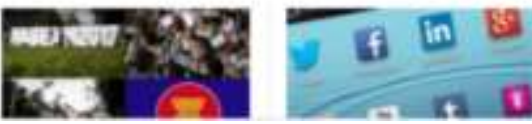

share your

photos

O it fint ans

Follow Us

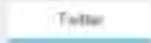

ล⿻一𠃋十

\section{Görsel 8 Yurttaş Gazetecilik MSNBC- Citizen Journalist Sayfası}

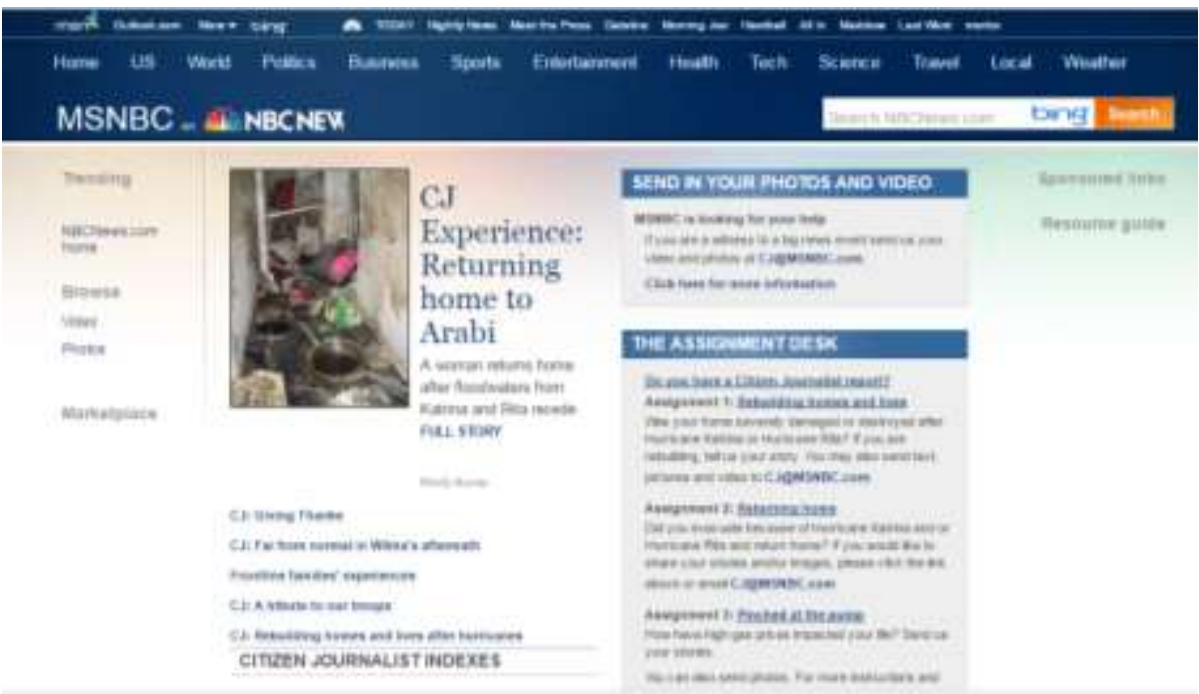




\section{Görsel 9 Milliyet Blog- Kendi Sayfasını Oluşturmuş Bir Yazar}

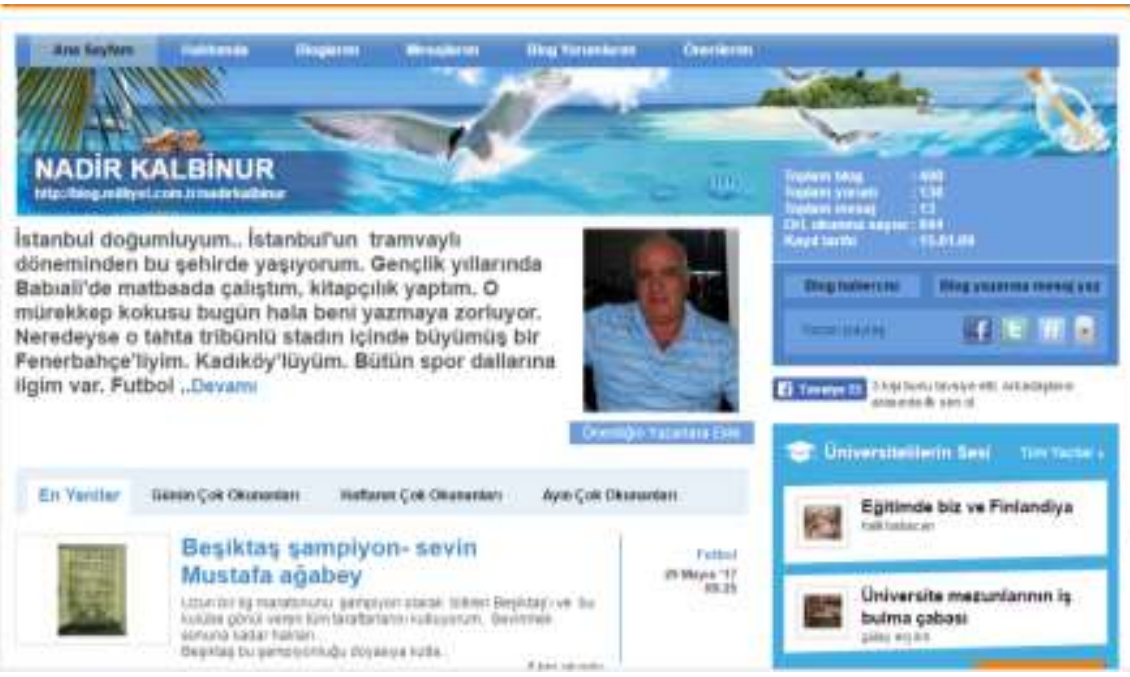

\section{Online Gazete: Paper Li}

Her şeyin biraz daha kişiselleştiği günümüzde artık herkes kendi adına online gazete çıkarabiliyor. Paper.li aslında kendisi içerik üretmeyen bir internet sitesi. Yaptığı şey ise 'çok basit'; Twitter'da sizin ve takip ettiğiniz kişilerin paylaştığ 1 haber, resim ve video linklerini tarayıp bunlardan sizin beğenilerinize özel bir kişisel gazete derlemek. 24 saatte bir güncellenen gazetede bir önceki günün önemli gündem tweetlerini gazete arayüzü ile okunup, güncel kalınabilir. Bu sayede örneğin bir blog yazarı, kendi izledikleri kişiler ve internet sitelerinden oluşan bir derleme servisi üzerinden yazar konumundan yayın yönetmeni konumuna terfi ediyor. Sosyal medyada zengin paylaşımlar yapan ve bu paylaşımları kişisel sosyal ağlarında geniş kabul gören kişiler, internet dünyasının yeni yıldızları oluyor.

\section{Görsel 10 Yurttaş Gazetecilik- Kendi Sayfasını Oluşturmuş Bir Kullanıcı}

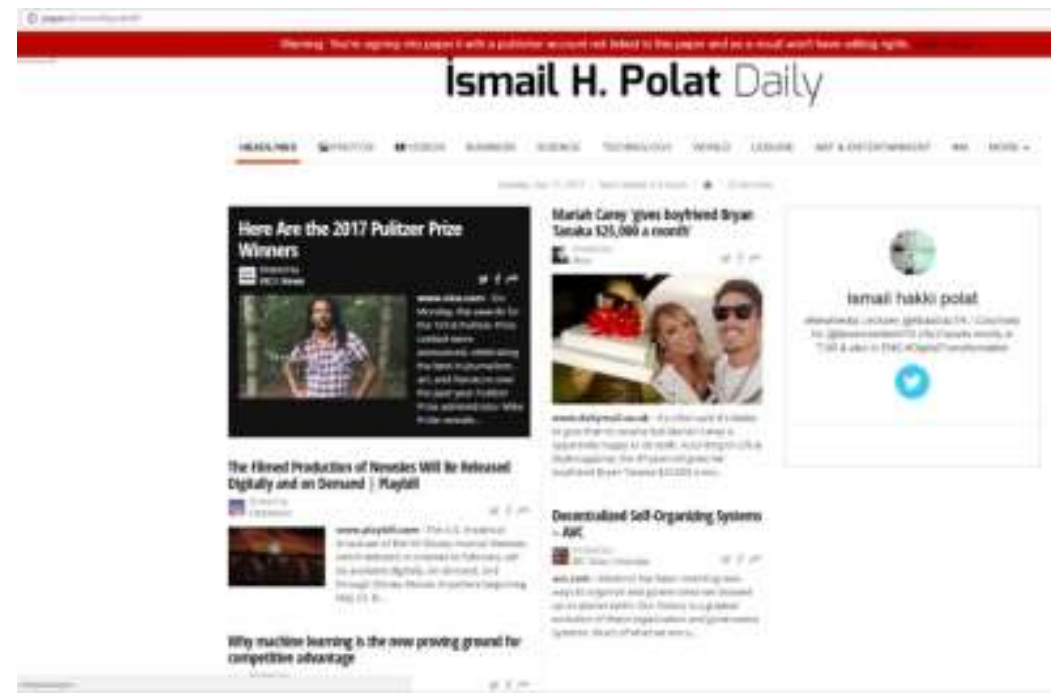




\section{Yeni Gazetecilik Modeli: Periscope}

Özgür, bağımsız ve patronsuz kitlelere ulaşabiliyorsunuz. Teknoloji konusunda en bilgisiz kişiler dahi tek tuşla, kolayca canlı yayın başlatabiliyor. Gezi Parkı olaylarında akıllı telefonlarla çektikleri video ve fotoğrafları paylaşmaya çalışanların çabasını fark eden İranlı girişimci Kayvon Beykpour'un, Amerika'ya döndüğünde ortağ Joseph Bernstein'le geliştirdiği bir sistem. Bu uygulamada görüntüyü kaydettikten sonra paylaşmak değil, anında yayına çıkmak söz konusu. Üstelik hem yayıncının hem yayını izleyenlerin yorum yapabilmeleri de mümkün.

\section{Görsel 11 Ruşen Çakır'ın Kurduğu Medyascope Sitesi}

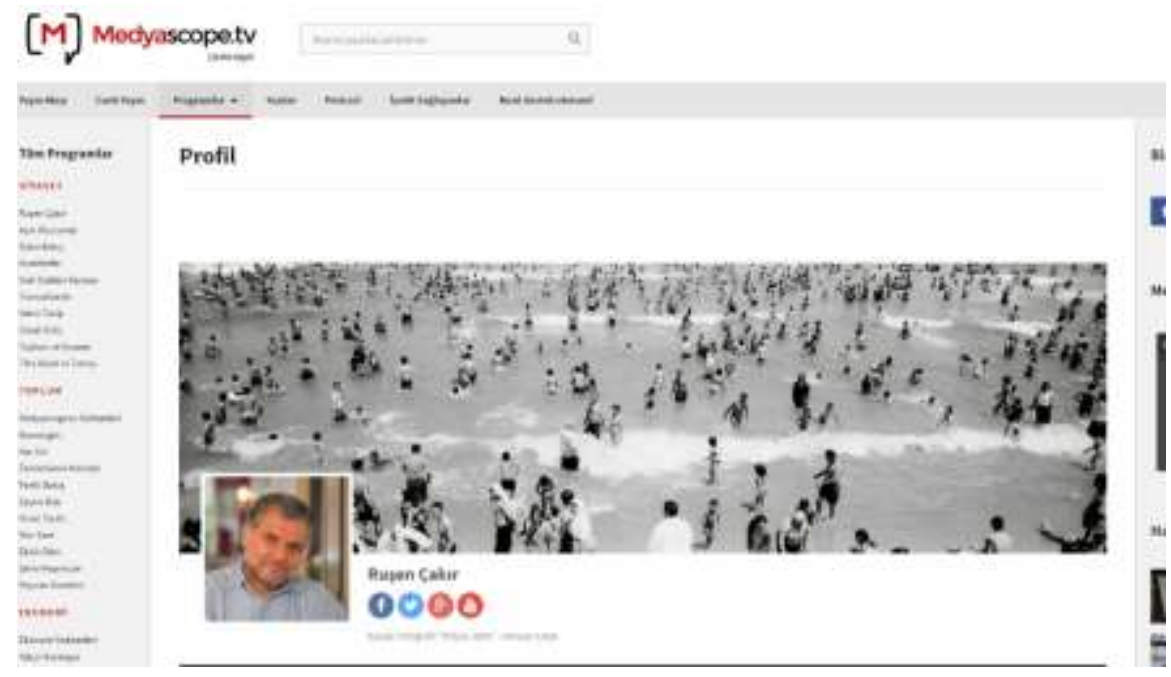

Artık yeni medya düzeninin hızlı, bağımsız bir oyuncusuyla karşı karşıyayız. Binlerce bağımsız yayıncı aynı anda canlı yayında... Üstelik sayıları da çı̆̆ gibi büyüyor. Kişisel ve kurumsal itibarın yönetilmesi artık daha zor. Zira her an her yerde birileri kayıtta ve yayında. Twitter'da gazetecilik nasıl gazeteciler ve ardından gelen duyarlı yurttaş gazetecilerle geliştiyse Periscope'ta da izlenecek nokta oldu. Medya kuruluşlarından önce Periscope'a el atan markalar çeşitli organizasyonlarını canlı olarak verdiler ve başarılı da oldular. Türkiye'de Ruşen Çakır Periscope'u en etkili kullanan gazetecilerin başında geliyor. Aynı zamanda kendisine ait Medyascope adlı bir sitesi var. Bu siteyle geleneksel medyaya adeta kafa tutuyor. NBC kanalının Tuscon haber istasyonu KVOA için çalışan Marisa Mendelson, ilk Periscope yayınını evinde gitar çalarak açınca birkaç gün içinde patronu tarafından bu APP'i kullanma diye uyarılmıştı. Profesyonel bir yaklaşım olmadığı ve bir muhabir olarak kanalını yanlış temsil ettiği kendisine belirtildi. Birkaç gün sonra köpeğiyle uyurken Periscope yayını yapan Mendelson ise KVOA tarafından kovulacaktı. Mendelson kovulduktan sonra ise; “TV kanalları Periscope'tan korkuyor, aslında korkmaları gereken şey Periscope değil. Korkmaları gereken gerçek şey internet. Çünkü yıllardır kendi sektörlerini öldürüyor" tweet atacaktı. 


\section{Yeni Medyada Gazeteciliğe Eleştirel Bakış ve Sonuç}

Genel olarak yeni medya üzerinden haber yapımına özel olarak da yurttaş gazeteciliğine yönelik bir dizi eleştiri de var. Bunların başında da yurttaş gazeteciliğinin profesyonel gazeteciliğin önemli değerlerinden objektifliğe pek de yer vermediği gelir. Ancak objektifliğin profesyonel gazetecilik için ne kadar evrensel bir değer olduğu da ne kadar uygulanabildiği de zaten tartışmalı bir konudur. Objektiflik öncelikle Amerikan gazetecilik geleneğinde bulunur, Avrupa kökenli gazetecilik geleneklerinde ise objektiflik iddiası hiçbir zaman öncelikli bir kriter olmamıştır (Pedelty, 1995). Uygulamaya gelince en objektif sayılabilecek Batılı medya kuruluşlarının bile sistematik önyargılara sahip olduğuna dair büyüyen bir literatür vardır. Savaş muhabirlerinin arasında yaptığı etnografik çalışmada Pedelty (1995) bu durumu gösterirken, Edward Said de aynı duruma söylemsel analizler sonucu işaret etmiştir. Her türlü gazetecilik faaliyetinde bir takım kriterlerin olması gerekiyor ama özellikle objektiflik bağlamında yurttaş gazeteciliği eleştirisi zayıf kalır.

Yurttaş Gazeteciler, hakkında yazdıkları toplumlar içinde birer aktivist de olabilmektedir. $\mathrm{Bu}$, halk gazeteciliği yanlılarını geleneksel objektiflik idealinin dışında hareket etmekle suçlayan New Yok Times gibi geleneksel medyadan bazı eleştirilerin gelmesine neden olmuştur. Birçok geleneksel gazeteci haber iletmekte bulunan eksiksizlik ve etikleri sadece eğitimli gazetecilerin anlayabileceğini düşünerek, yurttaş gazeteciliğine şüpheyle bakmaktadır. Bkz. Nicholas Lemann, Vincent Maher ve Tom Grubisich.

Rhodes Universitesi Yeni Medya Laboratuar Başkanı Vincent Maher'e ait akademik bir makale, yurttaş gazetecilerince etik, ekonomi ve epistomolojiye gönderme yapan "üç ölümcül E” hususunda öne sürülenlerdeki birkaç zayıflığın altını çizdi. Bu makale basın ve blog dünyasında eleştirilere neden olmuştur. Yurttaş gazetecilerin gerçek zamanlı haber yapabilmesi ve gözetime maruz olmaması gerçeği haberlerinin doğruluğu konusunda eleştirilere neden olurken, popüler medyaca sunulan yeni hikayeler de bazı zamanlar yurttaş gazeteciler tarafından doğru şekilde iletilen gerçekleri yanlış aktarmaktadırlar.

“Gazatecileri, kaynakları yayınlamaya karşı koruyan meşhur koruyucu yasalar bölgeden bölgeye değişmektedir. Koruma, zaman zaman iddiayı öne sürmekteki kişinin gerçekten bir gazeteci olup olmayışına bağlıdır. Sadece hakimlerin kimin gazeteci olup kimin olmadığını belirlediği bölgeler ve federal seviyelerde bunun birçok örneği bulunmakta. Yazılı suçlamanın bulunduğu durumlar sıklıkla aktörün "basının" bir üyesi olup olmamasına dayanmakta."

Yukarıda bahsedilen şey, profesyonel gazetecilerin koruyucu yasalarca tamamen korunduğu anlamına gelmemektedir. 1972 yılı Branzburg v. Hayes örneğinde, Birleşmiş Milletler Yüksek Mahkemesi, büyük jüri önünde tanıklık etmek üzere çağrılan gazeteciler için bir savunma olarak İlk Düzenlemenin kullamını reddetti. 2005'de Judith Miller ve Matthew Cooper'ın gazetecilik imtiyazları temyiz mahkemesince hükümsüz kabul edildi. (Çakmak, 2012) 
Yeni Medya ile birlikte bilgilerin hılıca sanal ortamda dolaşması bu bilgiler üzerinden manipülasyona da açık hale gelmiştir. Haberde fazla reyting alma adına toplumu infiale sürükleyici haber yapmaktan kaçınmıyorlar. İnternet ortamında yaşanan sorunlar İnternet sitelerinin editörleri ziyaretçilerini "okur" değil "tıklayıcı" olarak görmesi. Ne olursa olsun siteye trafik çekelim amaciyla okuru haber sitesinde olabildiğince uzun tutmak, oradan oraya dolaştırmak çünkü İnternet üzerinde ziyaretçilerin sadece binde 5'i reklamlara tıklıyor. Dolayısıyla bir reklamın tıklanma sayısını artırabilmenin ve daha çok para kazanmanın bilinen en iyi yöntemi o reklamı daha çok gösterebilmek İnternette reklam dışında para kazanmanın yönteminin henüz bulunamaması (Tunç, 2016)

Okurlar tükettikleri içeriğe ücret ödemezse ya da farklı bir gelir modeli üretilemezse ziyaretçi sayılarını korumaları ya da artırmaları gazetecilik faaliyetinin önüne geçmeye devam edecek.

Tüm bunlar için çözüm yolu olarak, Özneler arasında değerlendirme, kullanıcı haberlerin editöryal testi, kullanıcının haberleri puanlaması, kurum içi eğitimle gazetecilerin nefret söylemi, aldatma, manipülasyon konusunda bilgilendirilmesi, farklı bir gelir modeli yaratılması gibi seçenekler düşünülmelidir.

\section{Kaynakça}

Vardal, Z. B. (2015, Mayıs 1). Yeni Medya ve Etik.

YÜKSEL, U. (2012). Geleneksel Medya ve Yeni Medya.

Çakmak, D. (2012). dagmedya.net. dagmedya.net: https://dagmedya.net/2012/12/30/yurttas-gazeteciliginedir-ceviren-deniz-cakmak/ adresinden alındı

Karaduman, M. (tarih yok). TÜRKİYE'DE YENİ MEDYA ÜZERINNE BİR DEĞERLENDİRME: GAZETECİLIK, HABER VE ETIKK.

ÖZKAN, K. M. (2010, Aralık 8). Bireysel Gazetelerin Trajı Artıyor. kamilmehmetozkan.com: http://kamilmehmetozkan.com/wordpress/tag/twitter-haberciligi/\#.WSvkhOvyjIU adresinden alındı

ÖZTEKİN, H. (2015, Haziran). YEN MEDYADA NEFRET SÖYLEMİ: EKŞİ SÖZLÜK ÖRNEĞİ. Uluslararası Sosyal Araştırmalar Dergisi.

Saka, E. (2015). Yurttaş Gazeteciliği üzerine birkaç not. dehabertr: http://dehabertr.blogspot.com.tr/2015/11/yurttas-gazeteciligi-uzerine-birkac-not.html adresinden alındı

Tunç, A. (2016, Kasım 28). Bir 'tık' uğruna biten habercilik. t24.com: http://t24.com.tr/haber/bir-tikugruna-biten-habercilik,373600 adresinden alındı 
Vardal, Z. B. (2015, Mayıs 1). Yeni Medya ve Etik.

YÜKSEL, U. (2012). Geleneksel Medya ve Yeni Medya. 
AJIT-e: Online Academic Journal of Information Technology

2019 Bahar/Spring-Cilt/Vol: 10 - Sayı/Num: 37

DOI: 10.5824/1309-1581.2019.2.006.x 